\title{
Contribution of Volatile Interactions During Co-Gasification of Biomass with Coal
}

\author{
Joseph H. Kihedu ${ }^{a,{ }^{*}}$, Ryo Yoshiie ${ }^{a}$, Yoko Nunome ${ }^{b}$, Yasuaki Ueki ${ }^{b}$ and Ichiro Naruse ${ }^{b}$ \\ ${ }^{a}$ Graduate School of Engineering, Nagoya University, Furo-Cho, Chikusa-Ku, Nagoya, 464-8603, Japan \\ ${ }^{b}$ EcoTopia Science Institute, Nagoya University, Furo-Cho, Chikusa-Ku, Nagoya, 464-8603, Japan
}

\begin{abstract}
Thermo-gravimetric behavior during steam co-gasification of Japanese cedar and coal was investigated. The difference between co-gasification behavior and the average gasification behavior of cedar and coal indicates two synergetic peaks. The first peak occurred between $300{ }^{\circ} \mathrm{C}$ and $550{ }^{\circ} \mathrm{C}$ while the second peak was observed above 800 ${ }^{\circ} \mathrm{C}$. The first peak coincides with volatile release and therefore associated with volatile interactions while the second peak is linked with catalytic effect of alkali and alkaline earth metal (AAEM). Acid washed cellulose and Na rich lignin chemicals were used as artificial biomass components. In reference to Japanese cedar, mixture of cellulose and lignin i.e. simulated biomass, was also investigated. Co-gasification of cellulose with coal and co-gasification of lignin with coal, demonstrates contribution of volatile interactions and AAEM catalysis respectively. Morphology of partially gasified blends, shows hastened pore development and physical cracking on coal particles. Brunauer-Emmett-Teller (BET) surface area of the charred blend was lower than the average surface area for charred biomass and coal.
\end{abstract}

Keywords: Co-gasification, synergy, biomass, cellulose, lignin.

\section{INTRODUCTION}

Co-gasification of biomass and coal has several advantages including benefits of biomass as a renewable energy in addition to utilization of abundant coal [1]. Further advantages of co-gasification consist of the reduction of overall energy production cost as well as the reduction of environmental consequences resulting from coal utilization [2]. When biomass and coal are co-gasified, the resulting behaviors covering occurrence of synergy and mechanism of interaction are not clearly understood. Enhanced reactivity which occur during co-gasification have widely been linked with catalytic effects of AAEM [3-5]. In addition to that, some researchers have also reported that volatiles interactions also affects conversion characteristics [1, $2,6]$. To demonstrate the effect of AAEM catalysis, comparison of co-gasification of coal with biomass against co-gasification of coal with acid washed biomass have been used [4, 5]. Acid washing is possibly an effective method of AAEM removal, however some researchers have argued on its effects on the morphology and inherent chemical characteristics of the acid washed samples [7].

Compositions of lignin and cellulose are crucial factors in biomass reactivity during gasification $[5,8,9]$. Biomass with high cellulose content is relatively more reactive than biomass with higher lignin content $[5,10]$. Besides moisture removal process, decomposition of

*Address correspondence to this author at the Department of Mechanical and Industrial Engineering, University of Dar es Salaam, Tanzania; Tel: +81-52789-5123; Fax: +81-52-789-5123; E-mail: kihedu@udsm.ac.tz,

naruse@mech.nagoya-u.ac.jp biomass volatiles can be divided into two stages; cellulose decomposition and lignin decomposition. Cellulose decomposes fast between $300{ }^{\circ} \mathrm{C}$ and 400 ${ }^{\circ} \mathrm{C}$ while lignin decomposes slowly from $250{ }^{\circ} \mathrm{C}$ to 500 ${ }^{\circ} \mathrm{C}[5,8,11]$. If biomass is co-processed with coal, decomposition of volatile matters lowers the actual biomass-to-coal mass ratio in the charred blend since biomass has higher volatile matters in comparison to coal. Consequently, the resulting mass loss leads to relatively higher ash concentration within the charred blend and therefore AAEM catalysis is more effective at higher conversion stages $[4,5]$.

Japanese cedar and coal were used as primary parent fuels for studying co-gasification characteristics. In order to differentiate between the interactions phenomena and AAEM catalysis, acid washed cellulose [12] that has high volatile matters and $\mathrm{Na}$ rich lignin chemicals were used as artificial biomass components. As reference to Japanese cedar, gasification characteristics of simulated biomass, i.e. the mixture of $70 \%$ cellulose and $30 \%$ lignin by weight, was also investigated. In addition to that, cogasification of cellulose with coal and co-gasification of lignin with coal were also conducted. After partial gasification to $800^{\circ} \mathrm{C}$, BET surface area and morphology of the charred samples were also investigated.

\section{EXPERIMENTAL METHODS}

\section{Samples and Blending Ratios}

Japanese cedar (cryptomeria japonica) and coal were milled to $150 \mu \mathrm{m}$ and stored in a desiccator to 
avoid moisture contamination. lignin made by Kanto Chemical Co. Inc, and acid washed microcrystalline cellulose prepared by Sigma-Aldrich Chemie $\mathrm{GmbH}$ [12], were used as artificial biomass constituents. Proximate and ultimate analyses of these samples are shown in Table $\mathbf{1}$ while Table 2 shows analysis of inorganic matters contents. Separate gasification experiments were conducted for; cedar, cellulose, lignin and coal. In reference to cellulose and lignin contents in Japanese cedar [13, 14], simulated biomass was made by mixing cellulose and lignin at $70 \%$ and $30 \%$ dry and ash free (d.a.f.) mass basis. Cogasification of the samples mixed at 1:1 d.a.f. mass basis was conducted for the blend of cedar with coal, lignin with coal and cellulose with coal.

\section{Gasification Experiments}

Steam gasification of about $10 \mathrm{mg}$ samples was conducted by using Shimadzu Thermo-Gravimetric Analyzer (TGA). WORKlab water pump was used to supply distilled water to a steam generator set at 300 ${ }^{\circ} \mathrm{C}$. Heating rate from ambient temperature to $1,000{ }^{\circ} \mathrm{C}$ was set at $20^{\circ} \mathrm{C} \mathrm{min}^{-1}$, however holding at $107^{\circ} \mathrm{C}$ for $10 \mathrm{~min}$ to ensure complete removal of moisture contents from the samples. When $1,000{ }^{\circ} \mathrm{C}$ was attained, constant temperature gasification was allowed to proceed until no mass loss was observed. To avoid steam condensation within TGA reactor at lower temperature ranges, only $\mathrm{N}_{2}$ at $150 \mathrm{~mL}_{\mathrm{N}} \min ^{-1}$ was supplied from ambient temperature to $200{ }^{\circ} \mathrm{C}$. Thereafter, $\mathrm{N}_{2}$ flow was reduced to $75 \mathrm{~mL}_{\mathrm{N}} \mathrm{min}^{-1}$, and steam at $75 \mathrm{~mL}_{\mathrm{N}} \mathrm{min}^{-1}$ was supplied to allow gasification reactions to proceed. $\mathrm{N}_{2}$ supplied at 75 $\mathrm{mL}_{\mathrm{N}} \mathrm{min}^{-1}$ was maintained throughout the gasification process as purging gas and as a steam carrier.

\section{Analysis of Conversion Ratios and Extent of Synergy}

Conversion ratio $X$ (wt \%) was derived from mass decomposition data by TGA as follows;

$X=1-m / m_{0}$

where $m$ and $m_{o}$ (both in $g$ ) represent mass of the sample on d.a.f. basis at a certain gasification temperature and at initial condition, respectively.

Average conversion ratio $X_{\text {avg }}$ (wt \%) was calculated from conversion ratios for cedar, lignin, cellulose or simulated biomass $X_{b i o}$ and conversion of coal $X_{c o l}$ multiplied with mass ratio of the respective samples in the blend;

$X_{\text {avg }}=\left(X_{\text {bio }} \times m_{\text {bio }} / m_{\text {bld }}\right)+\left(X_{c o l} \times m_{c o l} / m_{b l d}\right)$

where $m_{c o l}$ and $m_{b l d}$ (both in g) represents initial d.a.f. mass of coal and the blend while $m_{\text {bio }}(\mathrm{g})$ represents d.a.f. mass of cedar, lignin, cellulose or simulated biomass.

Extent of synergy $Y(\%)$, was calculated as the difference between conversion ratio for blend $X_{b l d}$ from the calculated average conversion $X_{a v g}$ at the same temperature;

Table 1: Proximate and Ultimate Analyses of the Samples

\begin{tabular}{|c|c|c|c|c|c|c|c|c|c|}
\hline \multirow{3}{*}{ Sample } & \multicolumn{4}{|c|}{ Proximate analysis (wt, \%) } & \multicolumn{5}{|c|}{ Ultimate analysis (wt, \%) } \\
\hline & \multirow{2}{*}{$\begin{array}{c}\text { As received } \\
\text { Moisture }\end{array}$} & \multicolumn{3}{|c|}{ Dry basis } & \multicolumn{4}{|c|}{ Dry ash free basis } & \multirow{2}{*}{$\begin{array}{c}\text { Balance } \\
0\end{array}$} \\
\hline & & VM & FC & Ash & C & $\mathbf{H}$ & $\mathbf{N}$ & $\mathbf{S}$ & \\
\hline Coal & 2.00 & 30.30 & 56.00 & 13.60 & 80.97 & 1.47 & 9.32 & 0.45 & 7.79 \\
\hline Cedar & 3.90 & 86.09 & 11.79 & 2.13 & 47.56 & 5.66 & 0.27 & - & 46.51 \\
\hline Cellulose & 4.96 & 85.14 & 14.86 & $<0.01$ & 45.34 & 6.97 & 0.08 & - & 51.39 \\
\hline Lignin & 2.23 & 38.62 & 55.64 & 5.74 & 60.58 & 5.14 & 0.27 & - & 33.99 \\
\hline
\end{tabular}

Table 2: Ash Analysis for Inorganic Compounds

\begin{tabular}{|c|c|c|c|c|c|c|c|c|c|c|c|c|}
\hline \multirow{2}{*}{ Sample } & \multicolumn{12}{|c|}{ Inorganic compounds in the ash (wt, \%) } \\
\hline & $\mathrm{SiO}_{2}$ & $\mathrm{Al}_{2} \mathrm{O}_{3}$ & $\mathrm{CaO}$ & $\mathrm{TiO}_{2}$ & $\mathrm{Fe}_{2} \mathrm{O}_{3}$ & MgO & $\mathrm{Na}_{2} \mathrm{O}$ & $\mathrm{K}_{2} \mathrm{O}$ & $\mathbf{P}_{2} \mathbf{O}_{5}$ & MnO & $\mathrm{V}_{2} \mathrm{O}_{5}$ & $\mathrm{SO}_{3}$ \\
\hline Coal & 65.90 & 22.90 & 1.08 & 1.37 & 4.58 & 0.79 & 0.47 & 1.37 & 0.31 & 0.03 & 0.07 & 0.62 \\
\hline Cedar & 24.51 & 4.67 & 25.99 & 0.26 & 4.98 & 5.89 & 3.13 & 19.13 & 1.66 & - & - & 3.32 \\
\hline Lignin & 10.05 & 1.33 & 0.44 & $<0.01$ & 0.15 & 0.81 & 47.18 & 1.17 & $<0.01$ & - & - & 32.25 \\
\hline
\end{tabular}


$Y=X_{\text {bld }}-X_{\text {avg }}$

Investigation of Morphology and BET Surface Area

Morphology of the samples dried at $60{ }^{\circ} \mathrm{C}$ for 24 hours as well as the samples partially gasified at $20^{\circ} \mathrm{C}$ $\min ^{-1}$ to $800{ }^{\circ} \mathrm{C}$ was investigated by using Scanning Electron Microscope (SEM). BET surface area of the partially gasified samples was done by using Shimadzu Flowsorb Micrometrics whereby samples were degassed at $200{ }^{\circ} \mathrm{C}$ prior to adsorption of $\mathrm{N}_{2}$. During partial gasification, temperature profile as well as flow rates for $\mathrm{N}_{2}$ and gasifying agents, were similar to those applied during gasification experiments. However, when the target temperature of $800{ }^{\circ} \mathrm{C}$ was attained, heat supply and steam supply was terminated. Mean while the residues were allowed to cool under $150 \mathrm{~mL}_{\mathrm{N}}$ $\min ^{-1}$ supply of $N_{2}$. It can be noted that due to high temperature and possible presence of residual steam, it is most likely that further conversion of the residues occurred at initial stage of the cooling process to affect their morphology.

\section{RESULTS AND DISCUSSION}

\section{Conversion Behaviors and Extent of Synergy}

Conversion ratios during gasification at $20{ }^{\circ} \mathrm{C} \mathrm{min}^{-1}$ were calculated from mass decomposition data by using Equation (1). Conversion characteristics for Japanese cedar, coal and their blend is presented in Figure 1. It was observed that initial conversion of cedar, coal and the blend is marked by rapid change due to volatile decomposition. These rapid changes ended-up at around $400{ }^{\circ} \mathrm{C}, 700{ }^{\circ} \mathrm{C}$ and $450{ }^{\circ} \mathrm{C}$ respectively, corresponding to about $61 \%, 36 \%$ and $45 \%$ conversion. Thereafter, gasification of fixed carbon started at $750{ }^{\circ} \mathrm{C}, 950^{\circ} \mathrm{C}$ and $800{ }^{\circ} \mathrm{C}$ for cedar, coal and the blend, respectively. Average conversion was calculated from separate biomass gasification and coal gasification by using Equation (2). As from $400{ }^{\circ} \mathrm{C}$ and notably above $800{ }^{\circ} \mathrm{C}$, co-gasification characteristics shows improved trend in comparison to the calculated average. This improvement is an indication of occurrence of conversion synergy. Considering the slow heating rate of $20^{\circ} \mathrm{C} \mathrm{min} \mathrm{m}^{-1}$ used, the synergy occurring above $800^{\circ} \mathrm{C}$ can be related to AAEM catalytic effect [3-5] since volatile release will be less significant above this temperature range. However, synergy at the lower temperature range, can be also be associated with volatile interactions $[1,2,6]$.

In order to investigate AAEM catalysis and volatile interactions, we conducted experiments on cogasification of coal with $\mathrm{Na}$ rich lignin in addition to cogasification of coal with acid washed cellulose that has with high volatile matter content (Table 1 and Table 2). Firstly, we checked gasification characteristics of cellulose and lignin (Figure 2a). Gasification of cellulose is characterized by sharp devolatilization which occurs between $350{ }^{\circ} \mathrm{C}$ and $450{ }^{\circ} \mathrm{C}$, after which cellulose attain about $87 \%$ conversion corresponding to its high volatile matter contents (see Table 1). Lignin shows relatively slow volatilization limited to about $38 \%$ at $450{ }^{\circ} \mathrm{C}$. Gasification behavior of the simulated biomass compares well with that of Japanese cedar. However, simulated biomass shows the narrow temperature ranges for volatile decomposition and char gasification processes which occur at around $400{ }^{\circ} \mathrm{C}$

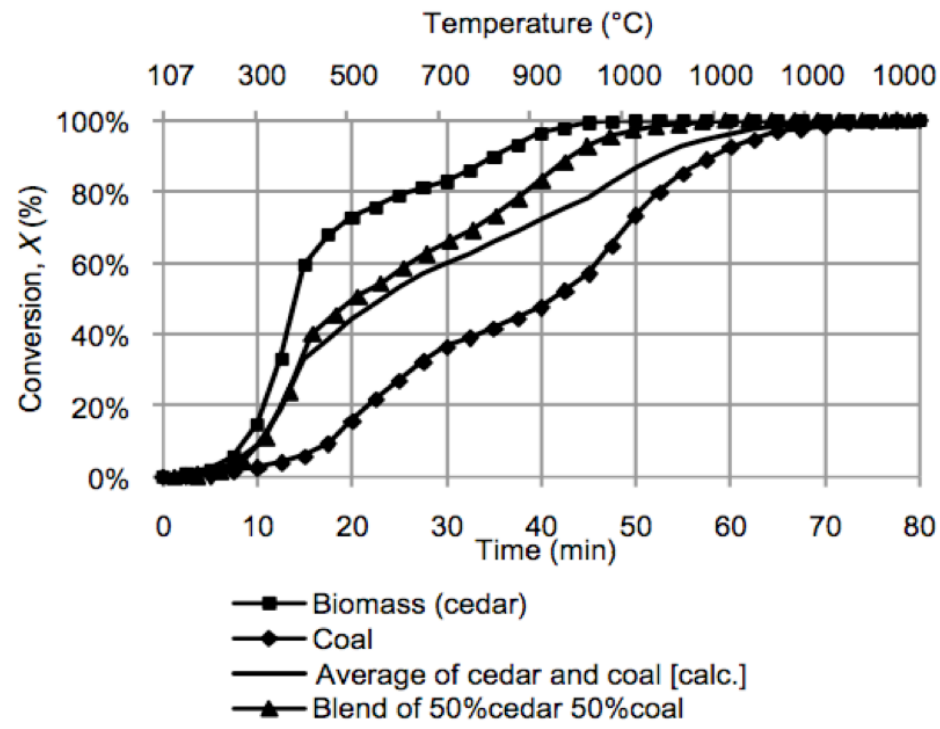

Figure 1: Conversion behavior of Japanese cedar, coal and the blend during steam gasification at $20^{\circ} \mathrm{C} \min ^{-1}$. 
Temperature $\left({ }^{\circ} \mathrm{C}\right)$

$\begin{array}{lllllllll}107 & 300 & 500 & 700 & 900 & 1000 & 1000 & 1000 & 1000\end{array}$

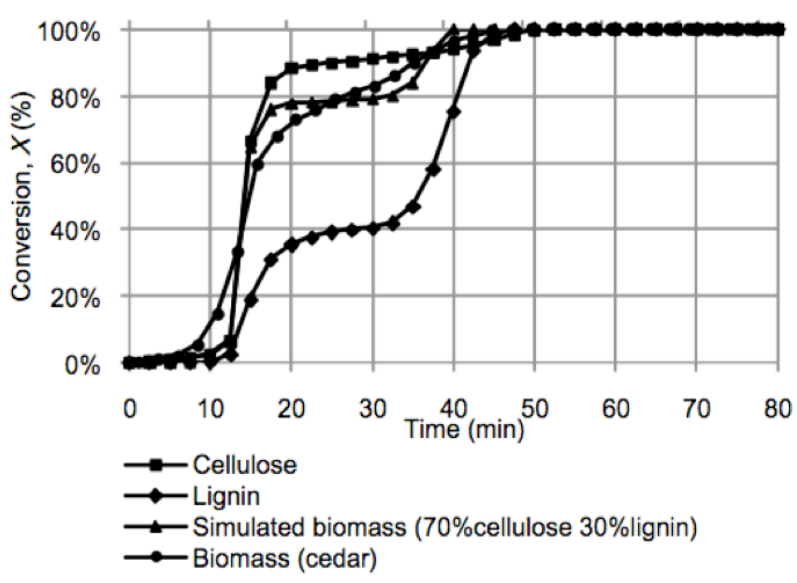

Temperature $\left({ }^{\circ} \mathrm{C}\right)$

$\begin{array}{lllllllll}107 & 300 & 500 & 700 & 900 & 1000 & 1000 & 1000 & 1000\end{array}$

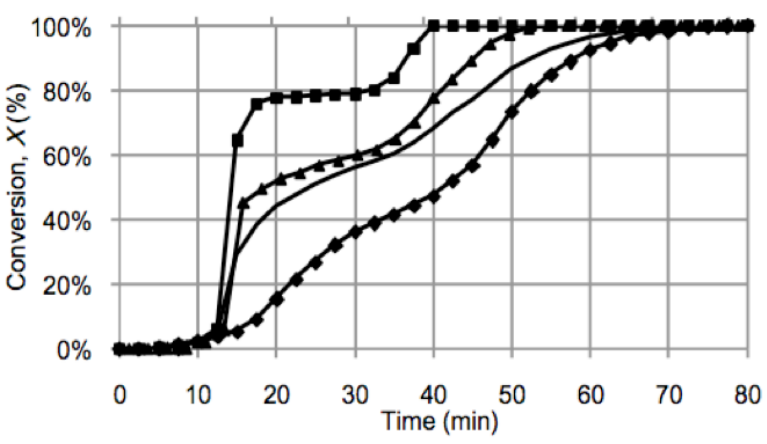

$\longrightarrow$ - Simulated biomass ( $70 \%$ cellulose $30 \%$ lignin)
$\longrightarrow$ Coal
$\longrightarrow$ Average of $50 \%$ simulated biomass $50 \%$ coal [calc.]
$\longrightarrow$ Blend of $50 \%$ simulated biomass $50 \%$ coal

Figure 2: (a): Conversion of cellulose, lignin, simulated biomass and cedar during steam gasification at $20^{\circ} \mathrm{C} \min ^{-1}$. (b): Conversion behavior of simulated biomass, coal and the blend during steam gasification at $20^{\circ} \mathrm{C} \mathrm{min}^{-1}$.

and $800{ }^{\circ} \mathrm{C}$ respectively. These patterns correspond to cellulose gasification and lignin gasification characteristics.

Co-gasification characteristic of simulated biomass with coal is presented in Figure $\mathbf{2 b}$. Two synergetic regions were observed as it was the case for cogasification of Japanese cedar with coal (Figure 1). Under both cases, it is difficult to demarcate between domination of the catalytic effect of AAEM and volatile interactions. Nevertheless, Figure $\mathbf{2 b}$ demonstrates the suitability of cellulose and lignin chemicals as artificial biomass components.

Co-gasification behavior of lignin with coal and cogasification of cellulose with coal are presented in

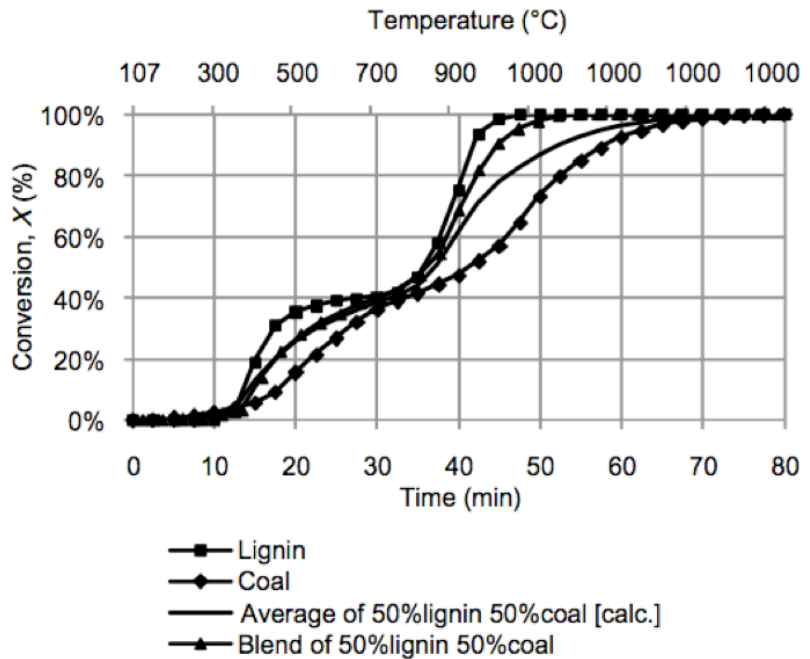

Figures $\mathbf{3} \mathbf{a}$ and $\mathbf{3} \mathbf{b}$, respectively. For the case of cogasification of lignin with coal, two synergetic regions were observed as it was the case for co-gasification of coal with either Japanese cedar or simulated biomass (Figures $\mathbf{1}$ and $\mathbf{2 b}$ ). Similarly, contribution of catalytic effect of AAEM and volatile interactions cannot be differentiated. On the other side, co-gasification of acid washed cellulose with coal shows synergetic pattern between $350{ }^{\circ} \mathrm{C}$ and $450{ }^{\circ} \mathrm{C}$ but no significant synergy is observed at temperatures above $800^{\circ} \mathrm{C}$ (Figure $\mathbf{3 b}$ ). This result indicates that synergy occurred during decomposition of cellulose volatiles and therefore associated with volatile interactions $[1,2,6]$.

The extent of the synergy for co-gasification of coal with Japanese cedar, simulated biomass, lignin or

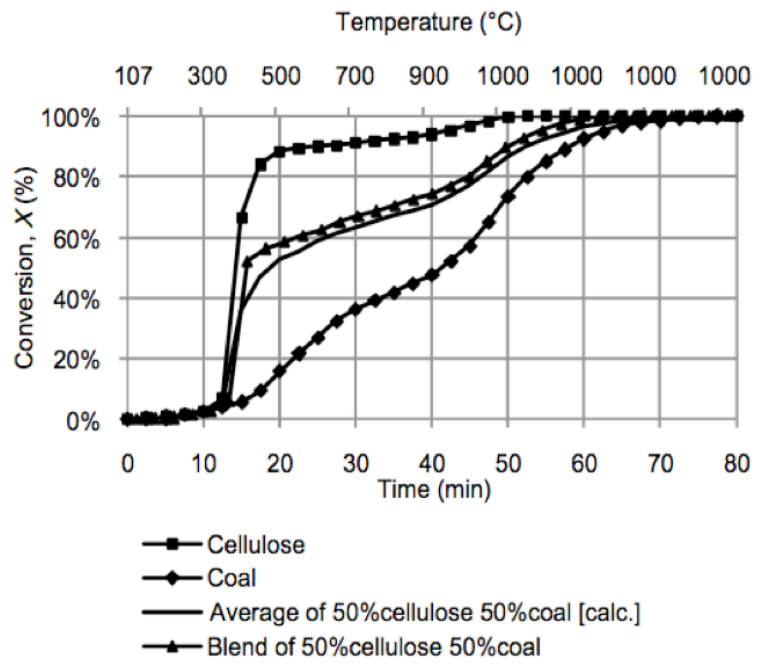

Figure 3: (a): Conversion behavior of lignin, coal and the blend during steam gasification at $20^{\circ} \mathrm{C}^{-1} \mathrm{~min}^{-1}$.

(b): Conversion behavior of cellulose, coal and the blend during steam gasification at $20^{\circ} \mathrm{C} \mathrm{min}^{-1}$. 


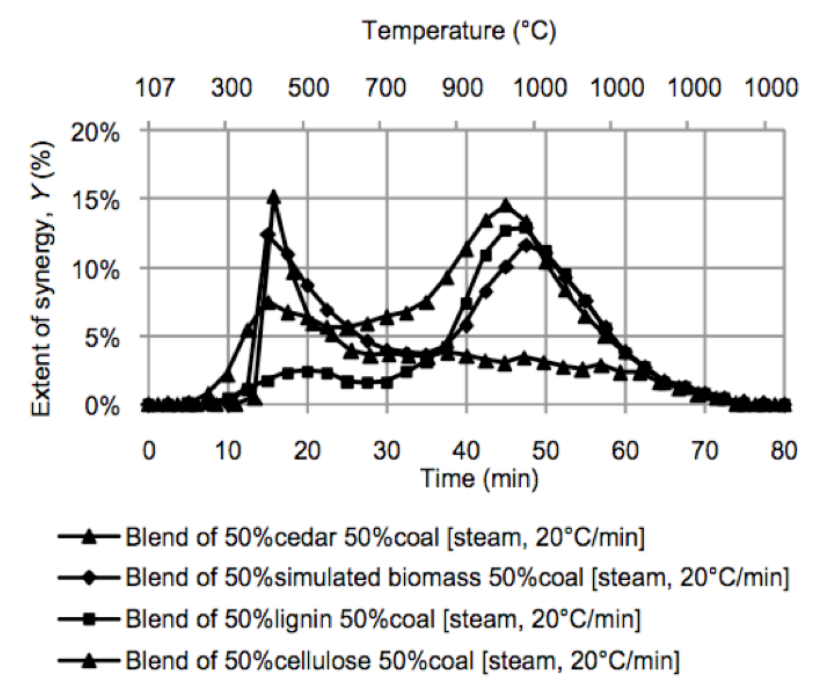

Figure 4: Extent of conversion synergy during co-gasification of coal with Japanese cedar, simulated biomass, lignin or cellulose at $20^{\circ} \mathrm{C} \mathrm{min}^{-1}$.

cellulose, was derived by using Equation (3). Two synergetic peaks were observed, the first one extending from $300{ }^{\circ} \mathrm{C}$ to $550{ }^{\circ} \mathrm{C}$ for all blends (Figure 4). The second peak occurred above $800{ }^{\circ} \mathrm{C}$, except for the blend of coal and acid washed cellulose. The first peak coincides with volatile release from Japanese cedar, simulated biomass, lignin and cellulose. The corresponding synergy can therefore be associated with volatile interactions $[1,2,6]$. Under slow heating TGA conditions used, most of volatiles decompose
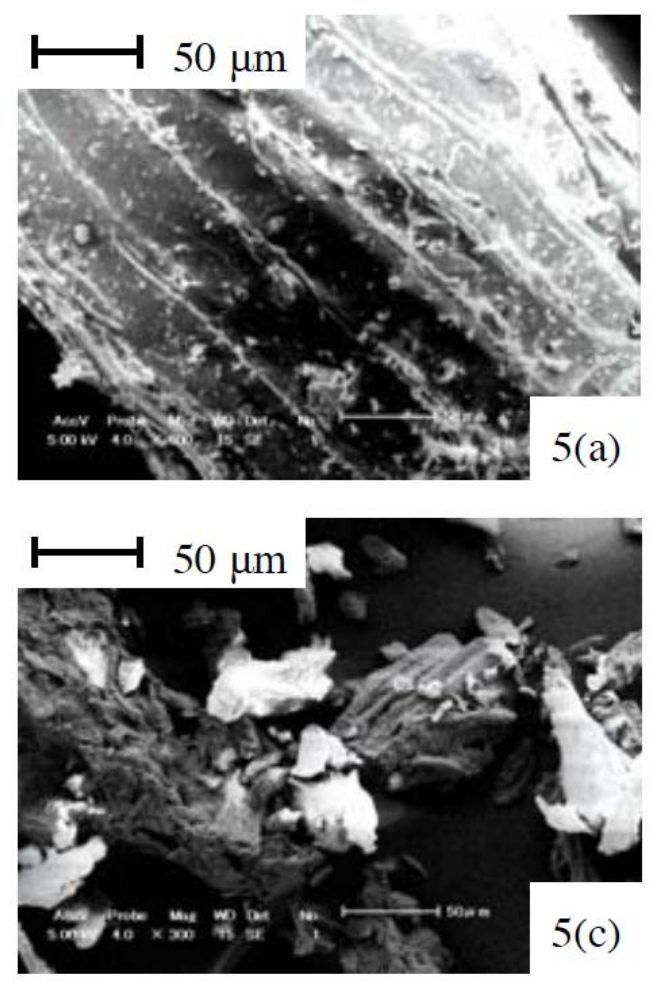

below $500{ }^{\circ} \mathrm{C}$ therefore the synergy which occurs at temperature ranges above $800{ }^{\circ} \mathrm{C}$ can be linked with AAEM catalysis. This figure suggests and demarcates two possible synergy mechanism; volatile interactions and AAEM catalysis which dominate at higher conversion stages $[4,5]$.

\section{Morphology Changes}

Morphology changes were investigated by comparing morphology of raw samples to the morphology of samples partially gasified to $800{ }^{\circ} \mathrm{C}$. SEM images of raw Japanese cedar, coal, cellulose and lignin are shown in Figure 5. Figure 5a shows that raw cedar has fiber based structure with multiple tubelike cells in contrast to coal which has solid structure and shiny surface (see Figure $5 \mathbf{b}$ ). Cellulose has solid fiber structure while lignin has lumpy solid structure (Figure 5c vs. Figure 5d).

After gasification to $800{ }^{\circ} \mathrm{C}$, samples indicate diverse morphological changes dependent to their intrinsic structures as well as conversion attained (Figure 6). Japanese cedar demonstrates remarkable morphology change (Figure 6a) owing to about $90 \%$ conversion attained at this stage (see Figure 1). The rectangular structure shown is indicative of the lignin based primary plant wall structure that is visible after decomposition of cellulose rich secondary wall [15].
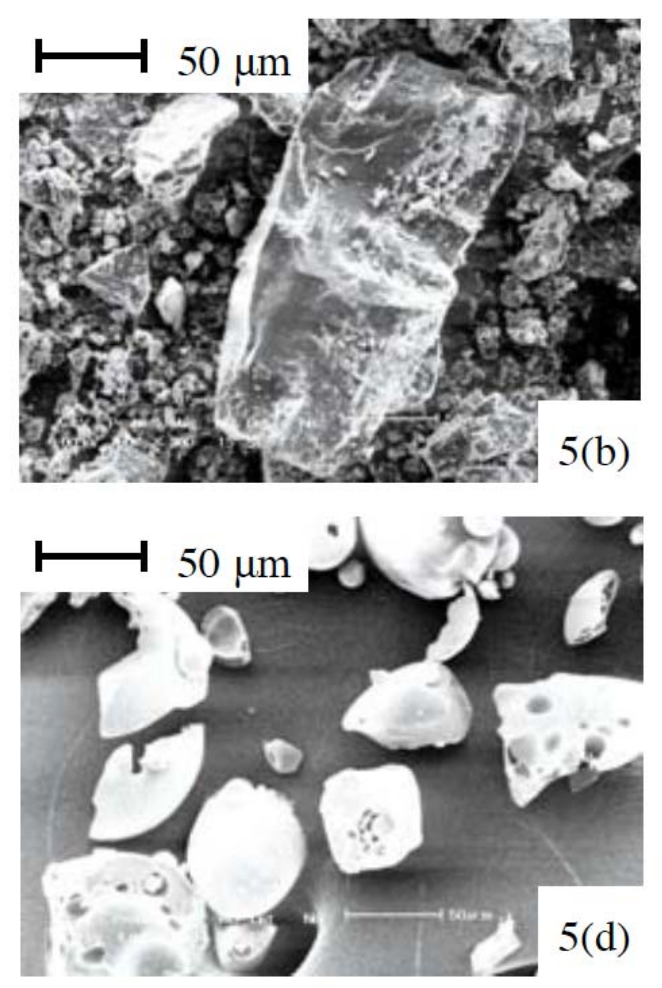

Figure 5: Morphology of the raw samples; (a) cedar, (b) coal, (c) cellulose, (d) lignin. 

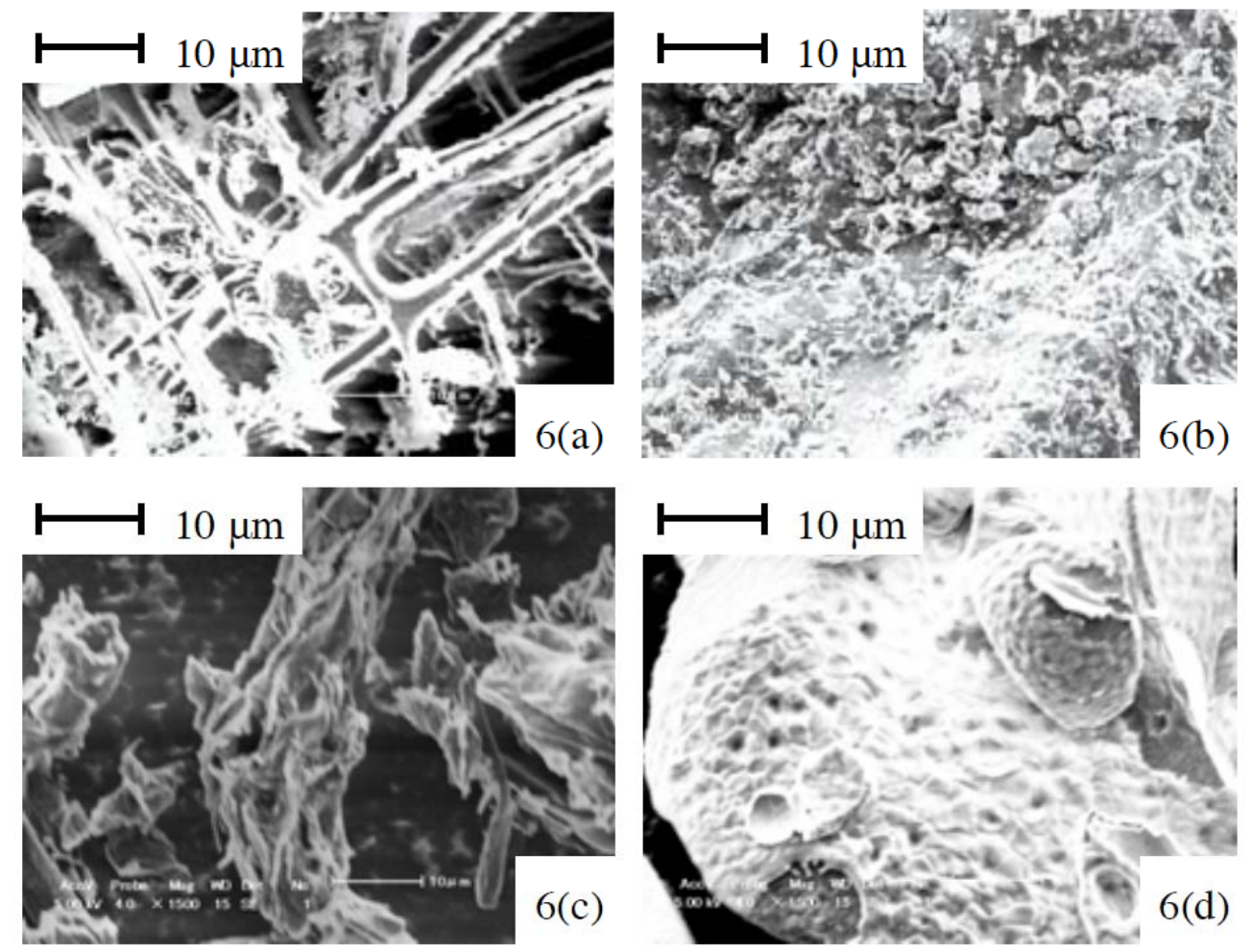

Figure 6: Surface structures after gasification to $800^{\circ} \mathrm{C}$; (a) cedar, (b) coal, (c) cellulose, (d) lignin.

Coal surface indicate pores development and slight physical cracking (Figure 6b). Nevertheless, coal particle seems to maintain its solid shape due to its low conversion of about $41 \%$ (Figure 1). Morphology change on cellulose is mainly based on fiber shrinkage basis (see Figure 6c). This shrinkage is attributed to decomposition of volatile matters which accounts for $85 \%$ of cellulose mass (Table 1 ). This is not the case with lignin which attained $46 \%$ conversion at $800{ }^{\circ} \mathrm{C}$ (Figure 2a). Despite of maintaining its solid shape as it is the case with coal, surface structure of a lignin particle shows spongy surface as shown in Figure $\mathbf{6 d}$. Probably, spongy surface offers less steam diffusion resistance and therefore enhancing the gasification process $[2,16,17]$ as observed from $800{ }^{\circ} \mathrm{C}$ onwards (see Figure 2a).

Morphology investigation was also conducted for partially gasified blends; cedar with coal, lignin with coal and cellulose with coal. Since reactivity of cedar, cellulose and even lignin is higher than that of coal, we focused on indication of the enhanced reactivity for coal particles. Figure 7 shows surface structures of coal particles taken from the co-gasified blends. After co-gasification with Japanese cedar, coal surface shows further pores development and physical cracking (Figure 7a). Enhanced pores and physical cracking on coal surface also applies for the case of the cellulose and coal as shown in Figure $\mathbf{7 b}$. However this effect is less pronounced in the case of cogasification of lignin with coal (Figure 7c). It can be noted that low extent of synergy was also observed for co-gasification of lignin with coal at temperature below $800{ }^{\circ} \mathrm{C}$ (Figure 4). Development of pores and physical cracking on coal surface may indicate enhanced conversion [16, 17]. In addition to that, these features may also play a significant role in enhancing intrinsic reactions through the resulting increase in reactive surface area and improved diffusion of steam into the coal matrix $[2,16,17]$.

\section{BET Surface Area}

BET surface areas for the samples partially gasified to $800{ }^{\circ} \mathrm{C}$ under steam gasification are shown in Figure 8. Inevitably, gasified cedar sample has higher BET surface areas than gasified coal sample as suggested by morphology presented in Figures $\mathbf{6 a}$ and $\mathbf{6 b}$. Average surface area for cedar and coal is shown as $373 \mathrm{~m}^{2} \mathrm{~g}^{-1}$ while the surface area of the blend is $308 \mathrm{~m}^{2}$ $\mathrm{g}^{-1}$. This result shows that average of the surface areas for coal and cedar is higher than the surface area of blend. It is known that BET surface area follows a bellytype profile against conversion, i.e. initially increases to a peak and hence decreases slightly at higher conversion stages $[18,19]$. As opposed to that, 

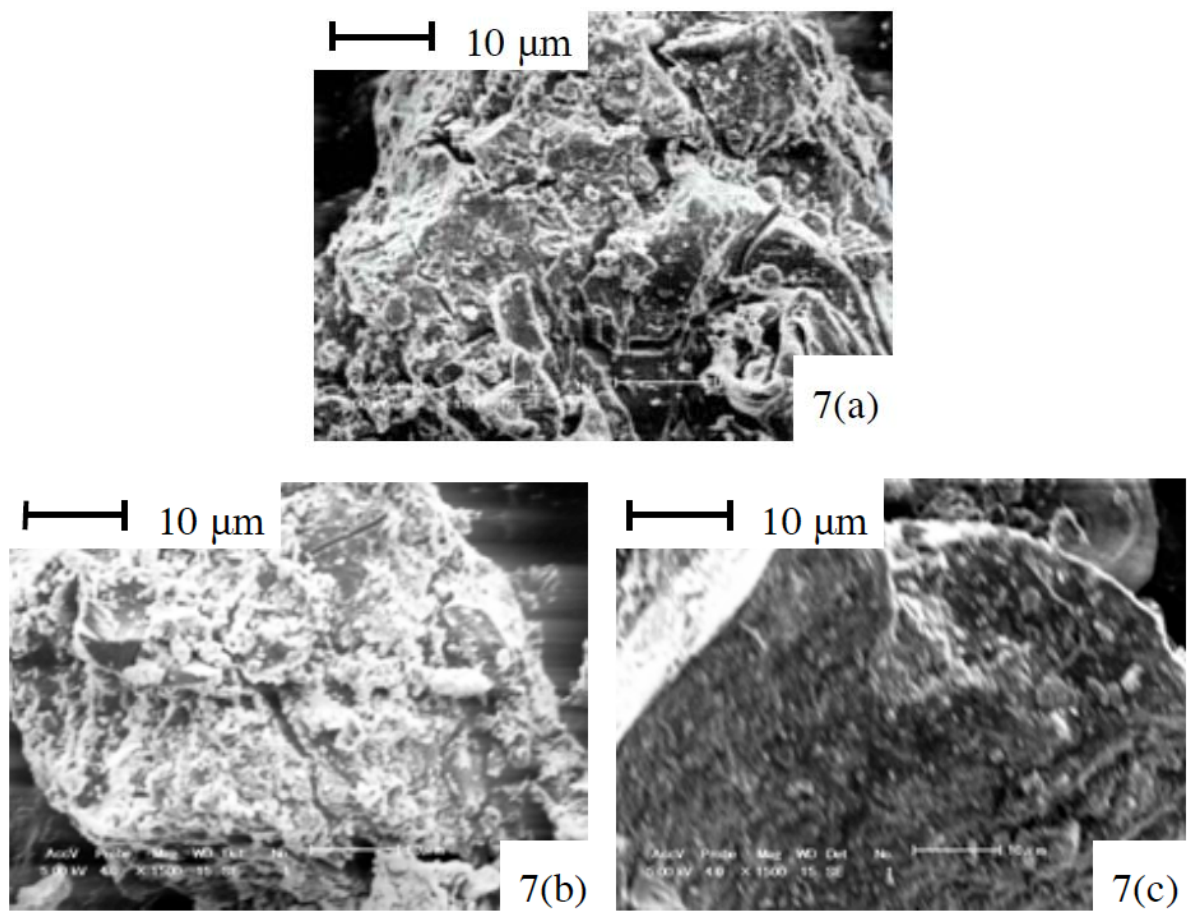

Figure 7: Surface structures after co-gasification to $800^{\circ} \mathrm{C}$; (a) coal surface from coal and cedar blend, (b) coal surface from coal and cellulose blend, (c) coal surface from coal and lignin blend.

conversion ratios increase to around 100\% (Figure 1 through Figure 4). Although it is difficult to explain synergy aspects by using this result, consideration of corresponding lower biomass to coal ratio at $800{ }^{\circ} \mathrm{C}$ suggests significant morphology improvement for coal particles as suggested by Figure $7 a$.

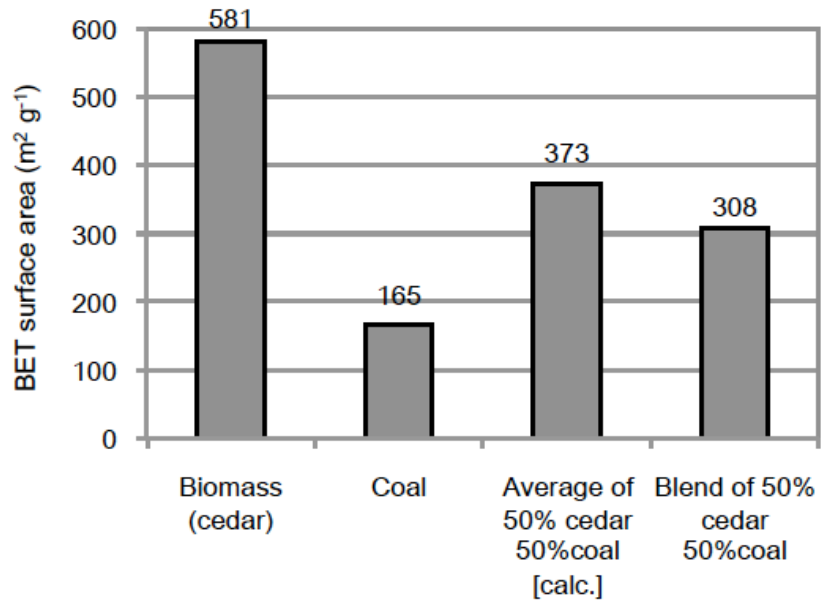

Figure 8: BET surface areas for Japanese cedar, coal and the blend gasified to $800{ }^{\circ} \mathrm{C}$.

\section{CONCLUSIONS}

Improved co-gasification conversion characteristic was observed in comparison to average conversion characteristics from separate gasification of cedar and gasification of coal. Two conversion synergetic peaks were observed, one extending from $300{ }^{\circ} \mathrm{C}$ to $550{ }^{\circ} \mathrm{C}$ while the other peak occurred above $800{ }^{\circ} \mathrm{C}$. The first peak coincides with volatile release and therefore associated with volatile interactions while the second peak can be linked with catalytic effect of AAEM species from biomass. In order to differentiate between the interactions phenomena and AAEM catalysis, acid washed cellulose that has high volatile matters and $\mathrm{Na}$ rich lignin chemicals were used as artificial biomass components. Co-gasification of cellulose with coal and co-gasification of lignin with coal elucidate volatile interactions phenomena and AAEM catalysis, respectively. Morphology of partially gasified blends, shows hastened pore development and physical cracking on coal particles. Average surface area for cedar and coal was about $373 \mathrm{~m}^{2} \mathrm{~g}^{-1}$ while the surface area of the blend was $308 \mathrm{~m}^{2} \mathrm{~g}^{-1}$.

\section{ACKNOWLEDGEMENTS}

Authors express their gratitude to MonbuKagakusho for funding this study. JHK extends appreciation to University of Dar es Salaam for a study leave.

\section{REFERENCES}

[1] Howaniec N, Smolinski A, Stanczyk K, Pichlack M. Steam co-gasification of coal and biomas derived chars with synergy effect as way of hydrogen-rich gas production. Int $\mathrm{J}$ Hydrogen Energ 2011; 26: 14455-63.

http://dx.doi.org/10.1016/j.ijhydene.2011.08.017 
[2] Sonobe T, Worasuwannarak N, Pipatmanomai S. Synergies in co-pyrolysis of Thai lignite and corncob. Fuel Process Technol 2008; 89: 1371-8. http://dx.doi.org/10.1016/j.fuproc.2008.06.006

[3] Blasi C. Combustion and gasification rates of lignocellulosic chars. Prog Energy Combust Sci 2009; 35: 121-40. http://dx.doi.org/10.1016/j.pecs.2008.08.001

[4] Zhu W, Song W, Lin W. Catalytic gasification of char from copyrolysis of coal and biomass. Fuel Process Technol 2008; 89: 890-6. http://dx.doi.org/10.1016/j.fuproc.2008.03.001

[5] Lv D, Xu M, Liu X, Zhan Z, Li Z, Yao H. Effect of cellulose, lignin, alkali and alkaline earth metallic species on biomass pyrolysis and gasification. Fuel Process Technol 2009; 91: 903-9. http://dx.doi.org/10.1016/i.fuproc.2009.09.014

[6] Haykiri-Acma H, Yaman S. Interaction between biomass and different rank coals during co-pyrolysis. Renew Energ 2010; 35: 288-92.

http://dx.doi.org/10.1016/j.renene.2009.08.001

[7] Suelves I, La'zaro MJ, Moliner R. Synergetic effects in the co-pyrolysis of coal and petroleum residues: influences of coal mineral matter and petroleum residue mass ratio. J Anal Appl Pyrol 2000; 55: 29-41. http://dx.doi.org/10.1016/S0165-2370(99)00072-8

[8] Gani A, Naruse I. Effect of cellulose and lignin content on pyrolysis and combustion characteristics for several types of biomass. Renew Energ 2007; 32: 649-61. http://dx.doi.org/10.1016/j.renene.2006.02.017

[9] Yang $\mathrm{H}$, Yan R, Chen $\mathrm{H}$, Lee DH, Zheng C. Characteristics of hemicellulose, cellulose and lignin pyrolysis. Fuel 2007; 86: $1781-8$. http://dx.doi.org/10.1016/j.fuel.2006.12.013

[10] Gottipati R, Mishra S. A kinetic study on pyrolysis and combustion characteristics of oil cakes: Effect of cellulose and lignin content. J Fuel Chem Technol 2011; 39: 265-70. http://dx.doi.org/10.1016/S1872-5813(11)60021-2
[11] Haykiri-Acma H, Yaman S, Kucukbayrak S. Comparison of the thermal reactivities of isolated lignin and holocellulose during pyrolysis. Fuel Process Technol 2010; 91: 759-64. http://dx.doi.org/10.1016/j.fuproc.2010.02.009

[12] Sigma-Aldrich [homepage on the Internet]. Tokyo, JP: Sigma-Aldrich Japan, [cited 2012 Dec 6]. Available from: http://www.sigmaaldrich.com/japan.html.

[13] Sagehashi M, Miyasaka N, Shishido H, Sakoda A. Superheated steam pyrolysis of biomass elemental components and Sugi (Japanese cedar) for fuels and chemicals. Bioresour Technol 2006; 97: 1272-83. http://dx.doi.org/10.1016/j.biortech.2005.06.002

[14] Take H, Andou Y, Nakamura Y, Kobayashi F, Kurimoto Y, Kuwahara M. Production of methane gas from Japanese cedar chips pretreated by various delignification methods. Biochem Eng J 2006; 28: 30-5. http://dx.doi.org/10.1016/j.bej.2005.08.036

[15] Salmén, L. Micromechanical understanding of the cell-wall structure. Comptes Rendus Biologies 2004; 327: 873-80. http://dx.doi.org/10.1016/j.crvi.2004.03.010

[16] Keown DM, Hayashi J-I, Li C-Z. Drastic changes in biomass char structure and reactivity upon contact with steam. Fuel 2008; 87: 1127-32 http://dx.doi.org/10.1016/j.fuel.2007.05.057

[17] Xu Q, Pang S, Levi T. Reaction kinetics and producer gas compositions of steam gasification of coal and biomass blend chars, part 1: Experimental investigation. Chem Eng Sci 2011; 66: 2141-8. http://dx.doi.org/10.1016/j.ces.2011.02.026

[18] Tay H-Z, Li C-Z. Changes in char reactivity and structure during the gasification of a Victorian brown coal: Comparison between gasification in $\mathrm{O}_{2}$ and $\mathrm{CO}_{2}$. Fuel Process Technol 2010; 91: 800-4.

http://dx.doi.org/10.1016/j.fuproc.2009.10.016

[19] Hurt RH, Sarofim AF, Longwell JP. The role of microporous surface in the gasification of chars from a sub-bituminous coal. Fuel 1991; 70: 1079-82. http://dx.doi.org/10.1016/0016-2361(91)90263-A 